\title{
A Personality of Andragogical Science: Dr. h. c. prof. PhDr. PaedDr. Ján Perhács, CSc.
}

\section{Ctibor Határ *}

Received: October 26, 2016; accepted: November 2, 2016

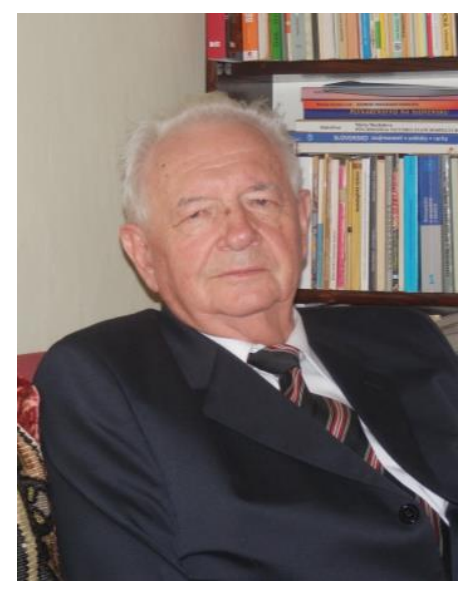

The current science dealing with the education of adults belongs to fully established human sciences. Until the year 1989, it was intensively being developed in our territory under the name of "Pedagogy of Adults" and since the year 1990, it has been called "Andragogy". Such a development is possible only thanks to many outstanding professionals. One of them is, indisputably, professor Ján Perhács who is now celebrating a very significant life anniversary of being 80 years old.

* Ctibor Határ, Constantine the Philosopher University in Nitra, Faculty of Education, Slovakia; chatar@ukf.sk 


\section{Acta Technologica Dubnicae \\ volume 6, 2016, issue 3}

Professor Ján Perhács graduated in the subject fields of Hungarian Language, Slovak Language and Pedagogy (1961). He passed his rigorous exams at the Faculty of Arts of Comenius University in Bratislava and at the University of Lóránd Eötvös in Budapest (1971 and 1978). In 1978, he earned his Candidate of Science degree in the subject field of pedagogy at the Hungarian Academy of Sciences in Budapest. He was awarded a Professor of Pedagogy in 1996 and, in the year 2005, the University of Pécs awarded him the degree of doctor honoris causa. Since the year 2009, professor Ján Perhács has been a honorable member of the committee of the Pedagogical and Andragogical Science of the Hungarian Academy of Sciences and since the year 2010, he has been a honorable member of the Czech Andragogical Society. At the same time, the professor is a holder of several national awards.

Professor Ján Perhács is one of those academic teachers who created their academic careers in connection with their practical experience of educational work at primary and secondary school $(1955-1962)$. In the years $1962-1973$ he already worked as an Assistant Professor and the Head of the Department at the then-called Pedagogical Institute in Nitra. From 1973 to 1975, he was a group leader at the Institute for Further Education of Teachers of the Comenius University in Bratislava. In 1975, he signed a contract with the Faculty of Arts of Comenius University in Bratislava where he worked as an Assistant Professor and later as an Associate Professor and Professor until the year 2002. In 2003, the professor returned to the present Department of Pedagogy at the Faculty of Education of the University of Constantine the Philosopher in Nitra where he worked until the year 2013.

His contribution to the development of the scientific and study subject field connected with the education of adults in the former Czechoslovakia and later also in independent Slovakia has been not only in the human area but mainly in the specialized-professional level. Besides his work on the scientific research projects of the Scientific Grant Agency which were approved to the individual departments thanks to him (I will mention his last solved projects VEGA SAV MŠ SR č. 1/2644/05: Theoretical Basics of Developing the Andragogical Pedeutology and Social Andragogy in Conditions of Social Practice of Education of Adults and VEGA SAV - MŠ SR č. 1/0244/08: Innovations of Professional Competences of Teachers and Social Andragogues), he was present at the foundation of the Andragogical Scientific School in Bratislava and also in Nitra. Professor Ján Perhács supervised 16 postgraduate students and he held the function of the chairman of the Corporate Specialization Committee for the postgraduate study field of Andragogy which resided at the Faculty of Arts of Comenius University in Bratislava by 2010. Professor Ján Perhács was also one of the founders of the Czechoslovak scientific periodical Andragogical Revue (Prague). 


\section{Acta Technologica Dubnicae \\ volume 6, 2016, issue 3}

Within his scientific research and pedagogical activity, professor Ján Perhács has mainly dealt with the theory of education of adults, rhetoric communication and social andragogy, the theoretical-methodological principles of which were set by him in the year 1990. He is the (co-)author of many book publications (scientific monographies, textbooks, an encyclopedia and a dictionary) and scientific studies published in local and foreign journals as well as proceeding books. At the same time, he is the editor of several scientific proceeding books. Until now, the professor's work has been abundantly quoted.

For many years, professor Ján Perhács cooperated very effectively and intensively with several local institutions in the area of education of adults, as well as with universities and foreign institutions.

In the personality of professor Ján Perhács, the educational science has found an excellent professional. The Slovak school system considers him to be a very qualified and responsible teacher, and for the wide laic and professional community he represents a very valuable friend and colleague. I wish you so that your scientific work finds its place also in the work of the current contemporaries of the andragogical science and so that your "human" heritage is present in the life of further generations of scientists, teachers and andragogues.

\section{Acknowledgement:}

The author of the presented profile, which has been elaborated on the basis of the below mentioned sources and personal memories of the author, would like to express his sincere gratitude to the professor's wife Ms. Valéria Perhácsová for checking the personal and professional biography and for providing the photograph of Dr. h. c. prof. PhDr. PaedDr. Ján Perhács, CSc., which is a part of this profile.

\section{References}

Perhács, J. (2011). Personalizačné a socializačné aspekty rozvoja osobnosti dospelých (2nd revised ed.). Prague: Rozlet a Česká andragogická společnost.

Register zamestnancov vysokých škôl. Ján Perhács. (2016). Retrieved from: http://www.portalvs.sk/regzam/default/detail/10616?mode=full\&do=filterF orm-submit\&name $=\mathrm{J} \% \mathrm{C} 3 \% \mathrm{~A} 1 \mathrm{n} \&$ surname $=\mathrm{Perh} \% \mathrm{C} 3 \% \mathrm{~A} 1 \mathrm{cs} \&$ sort $=$ surname\&employment_state $=$ no\&filter $=\mathrm{Vyh} \% \mathrm{C} 4 \% \mathrm{BEada} \% \mathrm{C} 5 \% \mathrm{~A} 5$

Vedecko-pedagogická charakteristika pracovníka Dr. h. c. prof. PhDr. PaedDr. Jána Perhácsa, CSc. z 23.02.2010. 